\title{
Biodegradation of natural bitumen by Providencia stuartii isolated from heavy oil contaminated soil
}

\author{
Ayangbenro A.S.* \\ Department of Microbiology, College of Biosciences, Federal University of Agriculture, Abeokuta, P.M.B. 2240, Abeokuta, Ogun State, \\ Nigeria.
}

Received: 13/10/2016, Accepted: 09/11/2016, Available online: 06/10/2017

*to whom all correspondence should be addressed: sinasegun@gmail.com

\begin{abstract}
Abundance and availability of unconventional petroleum has led to intensified exploitation and exploration of the bitumen reserves. This has however led to environmental pollution. This study investigated the ability of Providencia stuartii isolated from heavy oil polluted soil to degrade natural bitumen. Temperature, $\mathrm{pH}$ and incubation period were independent variables used for optimization of degradation while optical density was used as dependent variable. Optical density was measured using a UV-Vis spectrophotometer. Residual bitumen/degradation products were analyzed using gas chromatography- mass spectrometry (GC-MS). Optical densities obtained ranged from 0.002 to 0.408 . Optimum optical density of 0.408 was obtained at $40{ }^{\circ} \mathrm{C}$ and $\mathrm{pH} 7$ after 13 days of incubation. There were significant changes in the composition of bitumen after analysis with GC-MS with detection of new compounds due to degradation. The GC-MS results showed the presence of some degradation products such as benzene (1-butylhexyl), benzene (1-propylheptyl) and 23, 28-bisnor-17.ß.(h)-hopane. This study revealed the excellent ability of $P$. stuartii in degrading bitumen contaminated environment.
\end{abstract}

Keywords: Bitumen, Biodegradation, Hydrocarbon, Pollution, Providencia stuartii.

\section{Introduction}

Increase in human population worldwide has led to increased demand for petroleum products and other industrial chemicals. This has resulted in high percentage of toxic products been released into the air, water and soil, representing a potential environmental hazard (Vanishree et al., 2014). Processing and distribution of petroleum hydrocarbons as well as the use of petroleum products has led to contamination of the environment and has also contributed to localized loadings of polycyclic aromatic hydrocarbons (PHA) into the environment (Das and Chandran, 2010). Such loadings may occur through accidental and deliberate release of raw and refined products.
Contamination caused by petroleum hydrocarbon leads to various carcinogenic and neurotoxic effects on man. Control and treatment approaches are thus required to mitigate the hazardous effect of petroleum hydrocarbon (Singh and Chandra, 2014). Their removal becomes inevitable and several physical, chemical and biological methods are available. Biological methods are costeffective and eco-friendly (Vanishree et al., 2014). Hence biodegradation of petroleum hydrocarbon with microorganisms is an attractive option.

Milic et al., (2009) described biodegradation as a viable technology that utilizes naturally occurring microorganisms which transforms toxic substances to non-toxic compounds and is emerging as a promising technology for treatment of soil and groundwater contamination. It utilizes the metabolic versatility of microorganisms to degrade hazardous pollutants. Bioremediation aim to achieve a transformation of organic pollutants into harmless metabolites or mineralize the pollutants into carbon dioxide and water (Azubuike et al., 2016)

Yergeau et al., (2012) described bitumen as a dense and extremely viscous form of unconventional petroleum. It can also occur in some petroleum deposits as bituminous sands or oil sands, where it is found in combination with sand, clay and water. It is composed of hydrocarbons with high boiling point range and molecules with relatively low hydrogen to carbon ratio as well as highly condensed polycyclic aromatic hydrocarbons (Yoon et al., 2009; Fagbote and Olanipekun, 2010). Polycyclic aromatic hydrocarbon compounds contain complex chemicals which include carbon and hydrogen with a fused ring structure containing at least two benzene rings. Some PAH and their derivatives are highly toxic and their mutagenic and carcinogenic properties are the main risk to human health (Abdel-Shafy and Mansour, 2016).

Destruction of ecosystems and pollution from bituminous toxic wastes are the environmental hazards associated with bitumen exploration and exploitation (Adebayo et al., 2009). While complete elimination of these problems may be difficult to achieve, the aim is often to curtail environmental degradation (Nwachukwu, 2003). Hence, this study investigated the ability of the organism to 
degrade natural bitumen which contains heavy molecular weight hydrocarbons.

\section{Materials and Methods}

\subsection{Sample collection}

The sampling location and their coordinates are presented in Table 1. Soils impacted with asphalt were collected randomly from Odeda, Osiele and Isolu, in Odeda Local

Table 1. Sampling location and their coordinates
Government of Ogun State, Nigeria. Natural bitumen used in this study was obtained from Agbabu bitumen deposit in Odigbo Local Government of Ondo State. The unimpacted soil samples (control) were collected from the campus of Federal University of Agriculture, Abeokuta, Ogun State. Soil sample collection was carried out as described by Balogun and Fagade (2008). Samples were collected in sterile aluminum foil and stored at $4{ }^{\circ} \mathrm{C}$ until used. All samples were collected in triplicates.

\begin{tabular}{|c|c|c|c|}
\hline \multirow{2}{*}{$\frac{S / N}{1}$} & \multirow{2}{*}{$\begin{array}{c}\text { Sample collection location } \\
\text { Odeda }\end{array}$} & \multicolumn{2}{|c|}{ Coordinates } \\
\hline & & $07^{\circ} 13^{\prime} 3137^{\prime \prime} \mathrm{N}$ & $03^{\circ} 31^{\prime} 2203^{\prime \prime} \mathrm{E}$ \\
\hline 2 & Osiele & $07^{\circ} 13^{\prime} 3480^{\prime \prime} \mathrm{N}$ & $03^{\circ} 31^{\prime} 1355^{\prime \prime} \mathrm{E}$ \\
\hline 3 & Isolu & $07^{\circ} 12^{\prime} 918^{\prime \prime} \mathrm{N}$ & $03^{\circ} 26^{\prime} 1733^{\prime \prime} \mathrm{E}$ \\
\hline 4 & Agbabu & $06^{\circ} 21^{\prime} 546^{\prime \prime} \mathrm{N}$ & $04^{\circ} 29^{\prime} 2621^{\prime \prime} \mathrm{E}$ \\
\hline 5 & FUNAAB & $07^{\circ} 13^{\prime} 2543^{\prime \prime} \mathrm{N}$ & $03^{\circ} 26^{\prime} 614^{\prime \prime} \mathrm{E}$ \\
\hline
\end{tabular}

\subsection{Characterization of bacterial isolate}

The isolate was identified on the basis of its colonial and cellular morphology. Biochemical characterization was done using API 20E identification kit (Biomérieux, France). API 20E kit was used according to manufacturer's instruction. The organism was further characterized using $16 S$ rRNA. The PCR amplification of 16S rRNA gene from the purified genomic DNA was carried out using universal primer sets. Sequencing of the gene was done and identification of the sequence was by Basic Local Alignment Search Tool (BLAST) with National Center for Biotechnology Information (NCBI) gene data base.

\subsection{Experimental design and statistical analysis}

The experiment was conducted using response surface methodology. Central Composite Design (CCD) of Design Expert 7.0.0. (Stat-Ease Inc., USA) was used for experimental design. Independent variables of temperature, $\mathrm{pH}$ and time) were considered while dependent response optical density were considered. The design involves 20 experimental sets which included 6 replicates at the central point based on the pattern generated through the software. Range of temperature for the degradation experiment was 23.18, 30, 40, 50 and $56.82^{\circ} \mathrm{C}$. $\mathrm{pH}$ was $0.27,3,7,11$ and 13.73 . The time intervals for degradation considered were $0,2,6,10$ and 12.73 days.

A functional factorial design was applied to derive a statistical model for the effects of the cultural conditions on degradation of bitumen by $P$. stuartii using CCD and to identify the combination of factors that would lead to the enhancement of degradation. The statistical package was used for regression analysis and graphical analysis of the data obtained during the experiment. Analysis of variance (ANOVA) was used to estimate the statistical parameters. The significance of the model equation and model terms were evaluated by F-test. The quality of fit of the polynomial model equation was expressed by the coefficient of determination $\left(R^{2}\right)$, adjusted $R^{2}$ and adequate precision. The fitted polynomial equation was expressed as three-dimensional surface plots to visualize the relationship between the responses and the experimental levels of each factor used in the design.

\subsection{Bitumen Degradation Experiment}

Bitumen degradation by $P$. stuartii was monitored in 250 $\mathrm{ml}$ Erlenmeyer flasks containing $99 \mathrm{ml}$ MSM with $1 \mathrm{~g}$ of bitumen as substrate. The optical density at $600 \mathrm{~nm}$ of the inoculum was adjusted to 0.5 using a spectrophotometer (Uniscope SM 7504 model, UK) before seeding into each flask. Degradation was evaluated by measuring optical density of the culture fluids at each time interval as biodegradation index (Oboh et al., 2006; Adebusoye et al., 2007). Control flasks were also set up in similar manner but without the isolate.

\subsection{Extraction}

The residual bitumen was extracted from the culture fluid with $50 \mathrm{~mL}$ of dichloromethane (DCM) in a separating funnel as described by Sojinu et al. (2011). The organic phase was drawn off and concentrated. Concentrated extracts were fractionated on glass column packed with activated silica and alumina (2:1) into aliphatic, aromatic, and polar fractions by successive elution with $20 \mathrm{ml}$ of hexane, $70 \mathrm{ml}$ of hexane/DCM (70:30 v/v) and $25 \mathrm{~mL}$ of methanol respectively.

\subsection{Gas Chromatography-Mass Spectrometry (GC-MS) Analysis}

The GC system (Agilent Technologies 7890A model) used for the analysis was equipped with Mass Spectrometer Detection 5975C (VLMSD) and injector (Auto) 7683B series. HP-5 Agilent technologies installed with an HP-DB5 column (length $30 \mathrm{~m}, 320 \mu \mathrm{L} \mathrm{I.D}$, and $0.25 \mu \mathrm{m}$ film thickness). Helium was used as carrier gas. The mass spectrometer was operated in the electron impact mode at $70 \mathrm{eV}$. The aromatic fractions were injected with an auto sampler in the splitless/split mode with a split time of $1 \mathrm{~min}$ after injection and the injector temperature was $280^{\circ} \mathrm{C}$. Column temperature was programmed from $50^{\circ} \mathrm{C}$ (held for $1 \mathrm{~min}$ ) to $150{ }^{\circ} \mathrm{C}$ at a rate of $10{ }^{\circ} \mathrm{C} / \mathrm{min}$, then to $210{ }^{\circ} \mathrm{C}$ at a rate of $2{ }^{\circ} \mathrm{C} / \mathrm{min}$ and finally to $280^{\circ} \mathrm{C}$ (held for $7 \mathrm{~min}$ ) at a rate of 
$35^{\circ} \mathrm{C} / \mathrm{min}$. Compound identification was by matching the spectral with that in the database of the 2011 National Institute of Standards and Technology (NIST) library (2011).

\section{Results}

The organism was a facultative anaerobe, Gram-negative rod which is motile and with the ability to oxidize glucose, saccharose, inositol, amygdalin and mannitol. It had the ability to utilize citrate, grew on MacConkey agar, produce indole, arginine dihydrolase and catalase positive. However, the organism does not produce hydrogen sulphide, acetoin, beta-galactosidase, gelatinase, lysine decarboxylase, deaminase and oxidase. The isolate was identified as Providencia stuartii which is closely related to Providencia stuartii strain ATCC 33672 with accession number NZ CP008920.1.

Table 2. Effect of different variables on the degradation of bitumen by Providencia stuartii

\begin{tabular}{c|c|c|c|c}
\hline Run & Factor 1 & Factor 2 & Factor 3 & Response \\
\hline 1 & $\begin{array}{c}\text { A: Temperature } \\
\text { (Degree Celsius) }\end{array}$ & B: $\mathbf{p H}$ & $\begin{array}{c}\text { Optical density } \\
\text { Absorbance }\end{array}$ \\
\hline 2 & 40.00 & 7.00 & 6.00 & 0.389 \\
\hline 3 & 30.00 & 11.00 & 2.00 & 0.056 \\
\hline 4 & 40.00 & 7.00 & 6.00 & 0.386 \\
\hline 5 & 40.00 & 7.00 & 12.73 & 0.408 \\
\hline 6 & 30.00 & 11.00 & 10.00 & 0.202 \\
\hline 7 & 40.00 & 7.00 & 6.00 & 0.381 \\
\hline 8 & 40.00 & 7.00 & 6.00 & 0.387 \\
\hline 9 & 23.18 & 7.00 & 6.00 & 0.370 \\
\hline 10 & 40.00 & 13.73 & 6.00 & 0.040 \\
\hline 11 & 56.82 & 7.00 & 6.00 & 0.381 \\
\hline 12 & 50.00 & 11.00 & 2.00 & 0.052 \\
\hline 13 & 40.00 & 7.00 & 6.00 & 0.383 \\
\hline 14 & 50.00 & 11.00 & 10.00 & 0.101 \\
\hline 15 & 50.00 & 3.00 & 2.00 & 0.020 \\
\hline 16 & 50.00 & 3.00 & 10.00 & 0.081 \\
\hline 17 & 30.00 & 3.00 & 10.00 & 0.076 \\
\hline 18 & 40.00 & 0.27 & 2.00 & 0.020 \\
\hline 19 & 30.00 & 3.00 & 0.00 & 0.016 \\
\hline 20 & 40.00 & 7.00 & 7.00 & 0.002 \\
\hline
\end{tabular}

The analysis of variance showed that the F-value (3315.17) for the regression model is significant and the lack of fit was not significant relative to the pure error (Table 3). This indicates that the model is adequate in approximating the response surface of the experimental design. Values of 'Prob > $F$ ' less than 0.0500 indicate model terms are significant. In this case $\mathrm{pH}$ and incubation period are significant model terms. The interactive effects of temperature and $\mathrm{pH}$, temperature and time, as well as $\mathrm{pH}$ and time were also found to be significant

Table 3. Analysis of variance for response surface cubic model

\begin{tabular}{cccccc}
\hline Source & Sum of squares & $\begin{array}{c}\text { Degree of } \\
\text { freedom }\end{array}$ & Mean square & F value & $\begin{array}{c}\text { p-value (Prob } \\
>\text { F) }\end{array}$ \\
Model & 0.56 & 14 & 0.040 & 3315.17 & $0.0001^{*}$ \\
A: Temperature & $6.050 \mathrm{E}-005$ & 1 & $6.050 \mathrm{E}-005$ & 5.04 & 0.0747 \\
$\mathrm{~B}: \mathrm{pH}$ & $2.000 \mathrm{E}-004$ & 1 & $2.000 \mathrm{E}-004$ & 16.67 & $0.0095^{*}$ \\
$\mathrm{C}:$ Time & 0.027 & 1 & 0.027 & 2216.26 & $<0.0001^{*}$ \\
AB & $1.625 \mathrm{E}-003$ & 1 & $1.624 \mathrm{E}-003$ & 135.8 & $<0.0001^{*}$ \\
$\mathrm{AC}$ & $1.152 \mathrm{E}-003$ & 1 & $1.152 \mathrm{E}-003$ & 96.00 & $0.0002^{*}$ \\
BC & $6.845 \mathrm{E}-004$ & 1 & $6.845 \mathrm{E}-004$ & 57.04 & $0.0006^{*}$ \\
$\mathrm{~A}^{2}$ & $1.654 \mathrm{E}-004$ & 1 & $1.654 \mathrm{E}-004$ & 13.78 & $0.0138^{*}$ \\
$\mathrm{~B}^{2}$ & 0.19 & 1 & 0.19 & 15842.00 & $<0.0001^{*}$ \\
$\mathrm{C}^{2}$ & 0.12 & 1 & 0.12 & 10320 & $<0.0001^{*}$ \\
Pure Error & $6.000 \mathrm{E}-005$ & 5 & $1.200 \mathrm{E}-005$ & & \\
Corrected Total & 0.56 & 19 & & &
\end{tabular}

Key:* significant model terms, A: Temperature, B: $\mathrm{pH}, \mathrm{C}:$ Time, $\mathrm{R}^{2}$ :Coefficient of determination, E: Exponential 
The optical densities obtained vary between 0.002 and 0.408 . The optimum growth response of 0.408 was observed at temperature of $40^{\circ} \mathrm{C}$ and $\mathrm{pH} 7$ after about 13 days of incubation. The central points have optical densities that ranged between 0.381 and 0.389 at $40{ }^{\circ} \mathrm{C}$ and $\mathrm{pH} 7$ after 6 days of incubation. The lowest response of 0.002 was obtained on the first day of incubation at $40{ }^{\circ} \mathrm{C}$ and $\mathrm{pH}$ of 7 (Table 2).

The response surface and contour plots of the modelpredicted responses were utilized to assess the interactive relationships between the significant variables. Each plot represented the effect of two independent variables, holding the other variables at constant levels. The shape of the corresponding contour plot indicated whether or not the mutual interaction between the independent variables is significant. As shown in Figures 1 and 2, each response surface plot of optical density indicates a clear peak, which meant that the optimum point was inside the design boundary well.

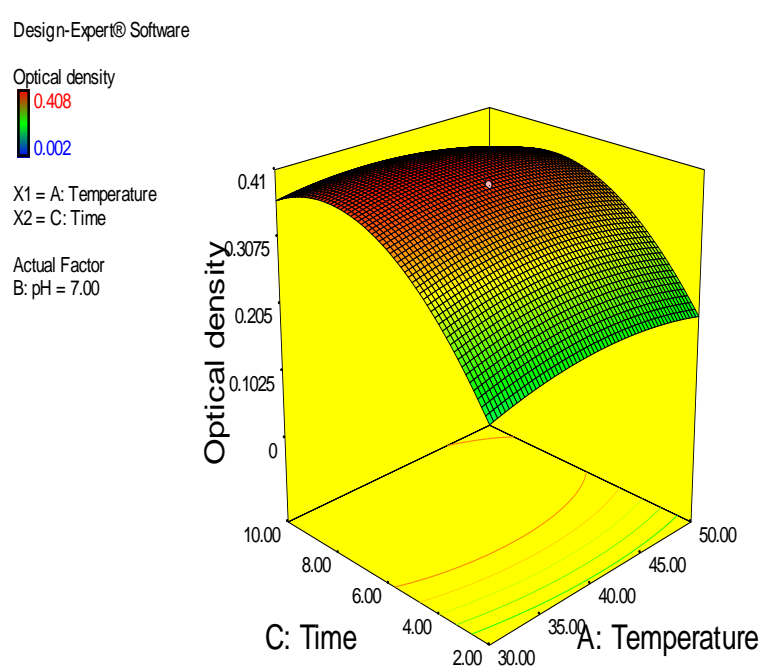

Figure 1. Effect of temperature and time on the optical density of $P$. stuartii.

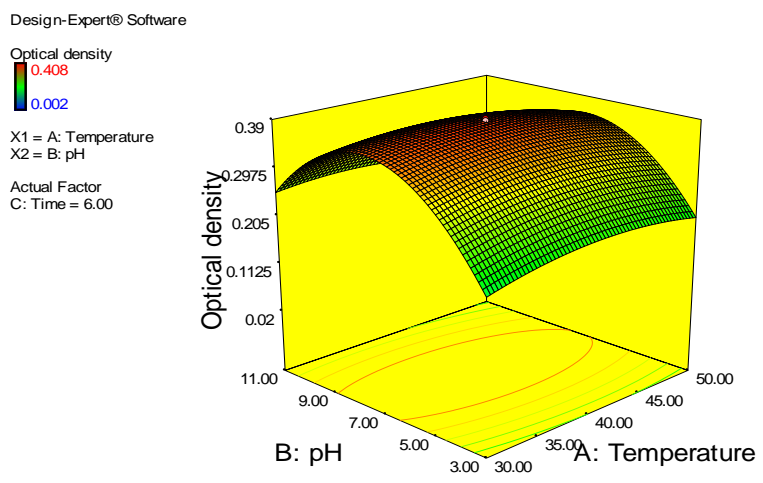

Figure 2. Effect of temperature and $\mathrm{pH}$ on the optical density of $P$. stuartii.
The effect of temperature and incubation period on the optical density of growth of $P$. stuartii while keeping $\mathrm{pH}$ constant at $\mathrm{pH} 7$ is depicted in Figure 1. The optical density increases with increase in incubation period while it increases with temperature up till the optimum temperature $\left(40^{\circ} \mathrm{C}\right)$. After $40^{\circ} \mathrm{C}$, the optical density sharply decreases. Figure 2 depicts the effect of temperature and $\mathrm{pH}$ on the optical density while keeping the incubation time constant at day 6 . Increase in $\mathrm{pH}$ and temperature up to the optimum $\mathrm{pH}(7)$ and temperature $\left(40{ }^{\circ} \mathrm{C}\right)$ increased the optical density to a maximum. Beyond the optimum, the trend is reversed.

The major compounds identified are benzene (1methyldecyl), benzene (1-ethyloctyl) and benzene (1butylhexyl) (Table 4) as identified by the NIST library.

Table 4. New and novel products identified in the degradation of bitumen by $P$. stuartii

Compound Name
(1-butylhexyl) benzene
(1-propylheptyl) benzene
(1-ethyloctyl) benzene
(1-methylnonyl) benzene
(1-methyldecyl) benzene
(1-methylundecyl) benzene
(1-ethylundecyl) benzene
(1-methyldodecyl) benzene
23,28-bisnor-17.ß.(h)-
hopane

\section{Discussion}

Biodegradation is a major mechanism for the removal of hydrocarbon pollutants from the environment and microorganisms play a crucial role in degradation. The genus Providencia has been reported to decolourize azo dye methyl red (Olukanmi et al., 2012) degrade oxalate (Hokama et al., 2005) and hydrocarbon (Augustynowicz et al., 2008). However, this organism has not been reported in literature to degrade heavy weight molecular hydrocarbon and the organism has shown a significant potential in bitumen degradation.

The enumeration of hydrocarbon degrading microorganisms is important to evaluate the amount of pollution that has occurred and to determine their potential for removal of oil through degradation (Youssef et al., 2010). They reported that the level of hydrocarbon utilizing microorganisms generally reflects the degree of contamination of the ecosystem. The isolation of hydrocarbon degrading microorganisms from unimpacted soil sample showed that almost all natural ecosystems contain population of bacteria that can metabolize some oil components and related compounds even if those systems have not been exposed to oil or oil products (Syvokiene and Micheniene.2004).

Biodegradation has been known to be influenced by temperature, $\mathrm{pH}$ and incubation period (Okoh, 2006; Balamurugan et al., 2011). These environmental conditions thus govern the efficiency and speed of microbial action on a substrate. The optimum temperature of $40{ }^{\circ} \mathrm{C}$ observed 
was in agreement with the works of Adebayo et al. (2009) and Olabemiwo et al. (2011). They observed that microbial attack of bitumen occurs at temperatures between 30-40 ${ }^{\circ} \mathrm{C}$. The optimum $\mathrm{pH}$ of 7 observed for the growth of $P$. stuartii on bitumen agreed with the work of Vanishree et al. (2014). They reported that the optimum $\mathrm{pH}$ for the degradation of hydrocarbon usually occurs at $\mathrm{pH}$ 6-8. Joshi and Pandey (2011) also reported that $\mathrm{pH} 7$ is suitable for biodegradation of hydrocarbon. Increase in optical density during treatment period indicates bacterial growth due to utilization of bitumen as a substrate and hence the degradation of bitumen (Oboh et al., 2006)

The $F$-value is a statistically valid measure of how well the factors describe the variation in the data about its mean (Sridevi et al., 2011). The greater the F-value is from unity, the more certain it is that the factors explain adequately the variation in the data about its mean, and the estimated factor effects are real. The determination coefficient $\left(R^{2}\right)$ value provides a measure of how much variability in the observed response values can be explained by the experimental variables and their interactions. The closer the $R^{2}$ value is to 1 , the stronger the model is and the better it predicts the optical density. In this case, the value of the determination coefficient $\left(R^{2}=0\right.$. 9999) indicates that 99.99\% of the variability in the optical density could be explained by the model. In addition, the value of the adjusted determination coefficient $\left(\operatorname{Adj} R^{2}=0.9996\right)$ is also very high to advocate for a high significance of the model.

The GC-MS results showed a number of compounds in the degraded bitumen listed in table 4 . When compared to hundreds of compounds in the raw bitumen, few compounds where found in the degraded bitumen. However, there is the need to see the possibility of further degradation.

\section{Conclusion}

This study showed that $P$. stuartii is capable of utilizing bitumen as a carbon source. This is a crucial mechanism in the removal of heavy weight molecular hydrocarbon from the environment, thus mitigating against possible environmental pollution.

\section{Conflict of Interests}

The author declares that there is no conflict of interests regarding the publication of this paper.

\section{References}

Abdel-Shafy H.I and Mansour M.S.M (2016), A review on polycyclic aromatic hydrocarbons: Source, environmental impact, effect on human health and remediation, Egyptian Journal of Petroleum, 25, 107-123.

Adebayo E.A., Oloke J.K. and Aina D.A. (2009), Optimization of cultural conditions for bitumen-degrading bacteria, Acta Satech, 3, 70-75.

Adebusoye S.A., Ilori M.O., Amund O.O., Teniola O.D. and Olaope S.O. (2007), Microbial degradation of petroleum hydrocarbons in polluted tropical stream, World Journal of Microbiology and Biotechnology, 23, 1149-1159.

Augustynowicz J., Kaszycki P., Kuś M., Białecka A. and Kołoczek H. (2008), Optimized methods for stabilization of microbial communities specializing in biodegradation of organic environmental contaminants, Polish Journal of Environmental Study, 17, 655-664.

Azubuike C.C., Chikere C.B. and Okpokwasili G.C. (2016), Bioremediation techniques-classification based on site of application: principles, advantages, limitations and prospects, World Journal Microbiology and Biotechnology, 32(180), doi 10.1007/s11274-016-2137-x.

Balamurugan P., Preetha B., Muthamilselvi P. and Viruthagiri T. (2013), Application of statistical design for biodegradation of phenol using Aspergillus fumigatus, Journal of Chemical, Biological and Physical Sciences, 3, 727-735.

Balogun S.A. and Fagade O.E. (2008), Screening for surface-active agent producing bacteria from diesel oil polluted tropical soil, World Applied Sciences Journal, 3, 930-933.

Das N. and Chandran P. (2010), Microbial degradation of petroleum hydrocarbon contaminants: An overview. Biotechnology Research International, 2011, Article ID 941810, 13 pages doi:10.4061/2011/941810.

Fagbote E.O. and Olanipekun E.O. (2010), Levels of polycyclic aromatic hydrocarbons and polychlorinated biphenyls in sediment of bitumen deposit impacted area, International Journal of Environmental Science and Technology, 7, 561-570.

Hokama S., Toma C., Iwanaga M., Morozumi M., Sugaya K. and Ogawa Y. (2005), Oxalate-degrading Providencia rettgeri isolated from human stools, International Journal of Urology, 12, 533-538.

Joshi R.A. and Pandey G.B. (2011), Screening of petroleum degrading bacteria from cow dung, Research Journal of Agricultural Sciences, 2, 69-71.

Milic J.S., Beskoski V.P., Ilic M.V., Ali S.A.M., Gojgic-Cvijovic G.D. and Vrvic M.M. (2009), Bioremediation of soil heavily contaminated with crude oil and its products: composition of the microbial consortium, Journal of Serbian Chemical Society, 74, 455-460.

National Institute of Standards and Technology library. (2011), The U.S. Secretary of Commerce on behalf of the United States of America.

Nwachukwu J.I. (2003), Exploitation of the bitumen deposits of Nigeria, In: Prospects for investment in mineral resources of southwestern Nigeria, Elueze A.A. (Ed.), Nigerian Mining and Geosciences Society, pp, 67-74.

Oboh B.O, Ilori M.O., Akinyemi J.O. and Adebusoye S.A. (2006), Hydrocarbon degrading potentials of bacteria isolated from a Nigerian bitumen (tar sand) deposit, Nature and Science, 4, 51-57.

Okoh A.I. (2006), Biodegradation alternative in the cleanup of petroleum hydrocarbon pollutants, Biotechnology and Molecular Biology Review, 1, 38-50.

Olabemiwo O.M., Adediran G.O., Adekola F.A., Adelowo O.O. and Olajire A.A. (2011), Preliminary Study on Biodegradation of Nigerian Natural Bitumen, Microbiology Journal, doi: 10.3923/mj.2011.

Olukanmi O.D., Adekola A.A., Sunmola D.B. and Osunmuyiwa O. (2012), Effect of redox mediators and various media on the decolourisation of the azo dye methyl red; and its biodegradation by Providencia rettgeri strain ODO, Environmental Engineering and Management Journal, 11(3) supplement, S15. 
Singh K. and Chandra S. (2014), Treatment of petroleum hydrocarbon polluted environment through bioremediation: a review, Pakistan Journal of Biological Sciences, 17, 1-8.

Sojinu O.S., Sonibare O.O. and Zeng E.Y. (2011), Concentrations of polycyclic aromatic hydrocarbons in soils of a mangrove forest affected by forest fire, Toxicological and Environmental Chemistry, 93, 450-461.

Sridevi V., Mahanti C.L., Adimadhyam S.V. and Medicherla N.R. (2011), Statistical optimization of process variables by response surface methodology to enhance phenol degradation by Pseudomonas putida (NCIM 2102), Advances in Bioscience and Biotechnology, 2, 175-181.

Syvokiene J. and Micheniene L. (2004), Impact of crude oil on bacteriocenosis of the digestive tract of Mollusks, Environmental Toxicology, 19, 421-424.

Vanishree M., Thatheyus A.J. and Ramya D. (2014), Biodegradation of petrol using Aspergillus sp., Annual Research and Review in Biology, 4, 914-923.

Yergeau E., Lawrence J.R., Sanschagrin S., Waiser M.J., Korber D.R. and Greer C.W. (2012), Next-generation sequencing of microbial communities in the Athabasca River and its tributaries in relation to oil sands mining activities, Applied Environmental Microbiology, doi:10.1128/AEM.02036-12.

Yoon S., Bhatt S.D., Lee H.Y., Jeong S.Y., Baeg J.O. and Lee C.W. (2009), Separation and characterization of bitumen from Athabasca oil sand, Korean Journal of Chemistry and Engineering, 26, 64-71.

Youssef M., El-Taweel G.E., El-Naggar A.Y., El- Hawary S.E., ElMeleigy M.A. and Ahmed S.A. (2010), Hydrocarbon degrading bacteria as indicator of petroleum pollution in Ismailia canal, Egypt, World Applied Sciences Journal, 8, 1226-1233. 